\title{
Loyalty and Word of Mouth of Muslim Women who Use Mobile Commerce in Indonesia
}

\author{
Saiful Anwar ${ }^{1 *}$, Mochlasin Mochlasin ${ }^{1}$, Rosana Eri Puspita ${ }^{1}$, Arna Asna Annisa ${ }^{1}$, Mohammad \\ Rofiuddin $^{1}$, and Rifda Nabila $^{1}$ \\ ${ }^{1}$ Faculty of Islamic Economics and Business, IAIN Salatiga, Salatiga-Indonesia \\ ${ }^{2}$ Faculty of Economics and Business, Sebelas Maret University, Surakarta-Indonesia
}

\begin{abstract}
The Covid-19 pandemic, which causes social distancing, has an impact on a surge of buying and selling through mobile commerce. On the other hand, customers are at the risk of online service failure in $\mathrm{m}$ commerce. This research tested the quality model of $\mathrm{m}$-commerce service that integrates the justice variable from the Islamic perspective on Muslim women's loyalty and word of mouth with satisfaction as the mediating variable and personal innovation and customer expertise as the moderating variables. This research is survey research involving 323 Muslim women who use the $\mathrm{C} 2 \mathrm{C} \mathrm{m}$-commerce platform services in Indonesia. Data analysis is presented in Structural Equation Modeling. The result shows that distributive justice, procedural justice, visual appeal, ease of use, and security influenced satisfaction, while information quality, load speed, and interactional justice did not affect satisfaction. This research proves that the principle of justice in buying and selling process for Muslim women exists in the m-commerce service so that it plays a positive role in satisfaction which has an impact on the loyalty and word of mouth of Muslim women. This research contributes to providing theoretical background as a service standard for m-commerce platforms that are user-friendly for Muslim women.
\end{abstract}

\section{Introduction}

Muslim Muslim women tend to have concerns about the Covid-19, which leads to increased behaviour in online shopping. On the other hand, the mobile commerce service system is still at risk of service failure. Several cases of incompatibility of products received with the information provided on mobile commerce often occur. Even the phenomenon of online purchases paid on the spot (Cash on Delivery) has failed and is detrimental to the sellers. Online shopping failure can be detrimental to the buyers, sellers, and platform provider. The failure of online shopping services has a negative impact on the company [1]. The success or failure of sellers in satisfying customers is determined by the quality service of mobile commerce [2]. E-service quality is the extent to which mobile commerce facilitates customers of products or services effectively and efficiently [3-4]. E-service quality by sellers is positively related to customer satisfaction, loyalty, and word-of-mouth $[3-5,10]$.

*Corresponding author:saifulanwarmieta@,iainsalatiga.ac.id 
There is no clear agreement on the dimensions of electronic service quality (e-service quality) [5]. In contrast to the findings of other researchers who found that security has an effect on satisfaction, loyalty and word of mouth [3, 10-11]. Load speed was found not to influence purchase intentions of online services [12]. Load speed has effected positively on satisfaction and intention loyalty of customers [10-11]. Other dimensional differences are also found in the dimensions of visual appeal. Visual appeal has the strongest influence on repurchase intentions [12].

Online shopping through mobile commerce eliminating face-to-face contact between sellers and buyers is undoubtedly an exciting issue from an Islamic perspective by Muslim women. This research tries to test the e-service quality of mobile commerce whether it has put forward justice theory in creating its interaction system with the primary users, Muslim women. Previous studies have assessed the e-service quality of customer interactions with online sites [5-7, 11-13]. E-service quality mobile commerce must convince Muslim women that buying and selling are fair, both in terms of price and quality as promised. Justice should be an integral part of e-service quality [14-15]. Justice empirically affects satisfaction [1517].

E-service quality in mobile commerce must involve skill variables and the personal innovativeness of Muslim women. Skills are needed in processing information better [18]. Advanced users tend to find more errors in a system [19]. Customer innovative behaviour has an important role in the assessment of service satisfaction [19-20]. This study aims to prove the effect of e-service quality on mobile commerce empirically as reflected by the ease of use, information quality, load speed, visual appeal, security and evidence of the existence of distributive justice, procedural justice, interactional justice on the satisfaction of Muslim women. The study also aims to empirically demonstrate the effect of Muslim women's satisfaction toward loyalty and word of mouth. In addition, this study tests the moderating variables of customer skill and personal innovativeness in moderating the relationship dimensions of electronic service quality with the satisfaction of Muslim women in Indonesia.

\section{Literatur Review and Hypotheses Development}

\subsection{Literatur Review}

\subsubsection{Technology Acceptance Model}

TAM is a theoretical model used to explain the use of an information technology system [21]. People's behaviour depends on how often the technology is used [22]. This theory has been used in a variety of many research to detect intentions [23-28]. The application of TAM in this study can help explain the intention of Muslim women to shop online using mobile commerce.

\subsubsection{Justice Theory}

This theory was initially known as the equity theory, which states that there is an effort to compare the output and input obtained in an honest exchange relationship. What is received can stimulate psychologically between transacting parties [29]. Injustice in transactions can be detrimental to personal [30]. There is a positive linear relationship between perceptions of fairness and job satisfaction [31]. The theory of fairness measures customer satisfaction with a service that tends to be satisfied with the service standards [32]. There are three types of justice used in this research: distributive justice, procedural justice, and interactional justice. Distributive justice refers to the extent to which investment is 
rewarded proportionally, returns on investment are in line with expectations, and results obtained with references are found [33]. Procedural justice is a measure of justice perceived by users that a process is carried out in accordance with existing regulations [34]. Interactional justice is a personal measure of being treated well with effective communication [35-36].

\subsection{Hypotheses Development}

E-service quality is the extent to which online services facilitate customers to shop online effectively and efficiently [3-4]. Assessment of e-service quality provided by sellers is not only limited to customer interactions with mobile commerce until completion. Eservice quality in this study is easy to use, information quality, load speed, visual appeal, security, interactional justice, distributive justice, and procedural justice. The ease of using mobile commerce in searching information and others will be relevant to satisfaction. Ease to use has a positive effect on satisfaction [3, 10, 11], [37-43]. The information quality obtained by Muslim women in mobile commerce encourages online shopping. Information quality plays a positive relationship in satisfaction [44-45].

Speed is a key factor for Muslim women in determining attitudes in accessing mobile commerce. The more real-time according to customer orders will have an impact on Muslim women's satisfaction. Load speed impacts satisfaction and, most potent creating customer dissatisfaction $[3,10]$. The visual appeal of mobile commerce will have a positive effect in creating satisfaction for Muslim women. Muslim women attach importance to visual appeal as entertainment when accessing mobile commerce [5, 10, 53, 13, 46-52]. Muslim women make security a reason to be careful in online shopping and switch to other applications if they feel mobile commerce is unsafe, such as research by Blut [3, 10, 54-57]. Security plays a positive relationship in Muslim women's satisfaction.

Investments in Muslim women that are rewarded relatively in terms of money, time, and energy will amplify the impact of satisfaction ratings after purchasing [15]. If Muslim women feel that their investment is not as promised by mobile commerce and sellers, they will judge it to be unfair. Distributive justice will strengthen Muslim women satisfaction after Muslim women. The treatment given by the mobile commerce system service plays a vital role in creating satisfaction for Muslim women. However, the system must be able to replace the face-to-face performance required in Islam. Interactional justice plays a crucial role in creating satisfaction for Muslim women on the quality of mobile commerce services due to limited contacts, such as the absence of face to face [1]. Procedural justice is the extent to which the existing procedures in mobile commerce are consistent, unbiased, balanced, and respect the interests of customers [15]. Muslim women will be satisfied if the existence of procedural justice in the mobile commerce service system. Procedural justice was the strongest factor for customer dissatisfaction in an online shopping environment [58]. Hypothesis one is the quality of mobile commerce services (a) ease to use, (b) information quality, (c) load speed, (d) visual appeal, (e) security, (f) distributive justice, (g) interactional justice, and (h) procedural justice has a positive effect on satisfaction Muslim women.

User characteristics affect service perceptions [59]. User skill is the knowledge and experience of customers about online shopping [60]. Skill can improve the quality of decision making [61]. The skill of Muslim women is knowledge gained from experience and training. The skill of Muslim women in using mobile commerce will later be used to assess the quality of services received $[18,60,62]$. Hypothesis 2 of this research is that user skill will moderate the relationship between mobile commerce services received by Muslim women. Innovativeness is the tendency in adopting a new service system [3]. Mobile commerce with a consumer-to-consumer system is a system that is currently growing and developing. User innovation affects satisfaction in the context of self-service technologies [20,63]. Hypothesis 
3, namely personal innovativeness, will moderate the relationship between the quality of mobile commerce services received by Muslim women.

Customers' satisfaction can create goodwill behave in the future as buy, visit, buyback, word of mouth, and loyalty [3-4, 7-9, 10, 13, 14, 54, 64-65]. Customer satisfaction will have a positive effect on repurchase intention [14]. Service quality influences customer behaviour intention through customer satisfaction [9]. In line with loyalty, Muslim women can recommend positive or negative things after their experience of doing online shopping. Hypothesis 4 of this research is that the satisfaction of Muslim women in using mobile commerce can increase loyalty behaviour. Hypothesis 5 of this study is that the satisfaction of Muslim women in using mobile commerce can increase word-of-mouth behaviour.

\section{Method}

Behavioral Behavioural loyalty and word of mouth by Muslim women are used quantitative approach with survey method. The respondents of this study were Muslim women who shopped online at least 2 times during the PSBB period. The survey instrument was developed with Likert 7 points $(1=$ strongly disagree, $4=$ neutral, and $7=$ strongly agree $)$ and first tested by pilot test. Item statement ease to use refers to Grandon and Pearson [66], information quality [45], load speed [67], visual appeal [46], security [3], distributive justice, interactional justice, procedural justice [14], Muslim women skill [60], Muslim women personal innovativeness [68], Muslim women Satisfaction [9], loyalty dan word of mouth [69]. This research uses purposive sampling to consider the following matters: (1) the respondent is the user of mobile commerce platform $(\mathrm{C} 2 \mathrm{C})$ customer to the customer at least two transactions during a pandemic; and (2) the respondent is female and is more than 23 years old. The selection of purposive sampling in this study is believed to provide an accurate description of the users of the e-commerce platform and in accordance with the objectives of this study.

After the data is collected, the data is processed using PLS-SEM to estimate the structured model. PLS-SEM uses two components, namely the inner Model and the outer Model. The outer model is used to assess the validity and reliability of the model. Validity was tested by convergent validity and discriminant validity. Convergent validity was tested on average variance extracted (AVE) and Communality with each value above 0.5. The value of crossloadings above 0.5 determining discriminant validity. The reliability test uses composite reliability with a value above 0.7 . The inner model is used to predict the causality relationship between variables. T-statistical test parameters were obtained to predict the existence of a causality relationship through bootstrapping. 


\section{Result and Discussion}

\subsection{Result}

Table 1. Validity and Reliability Construct.

\begin{tabular}{|l|c|c|c|c|}
\hline & AVE & Communality & $\begin{array}{c}\text { Result of } \\
\text { AVE root }\end{array}$ & $\begin{array}{c}\text { Composite } \\
\text { Reliability }\end{array}$ \\
\hline Ease to use & 0,657 & 0,657 & 0,814 & 0,912 \\
\hline Information quality & 0,662 & 0,652 & 0,823 & 0,922 \\
\hline Load speed & 0,663 & 0,667 & 0,898 & 0,894 \\
\hline Visual appeal & 0,570 & 0,562 & 0,758 & 0,874 \\
\hline Security & 0,810 & 0,800 & 0,912 & 0,933 \\
\hline Distributive justice & 0,787 & 0,778 & 0,887 & 0,956 \\
\hline Interactional justice & 0,920 & 0,928 & 0,932 & 0,969 \\
\hline Procedural justice & 0,612 & 0,574 & 0,756 & 0,888 \\
\hline Muslim women Skill & 0,823 & 0,884 & 0,923 & 0,944 \\
\hline Muslim women Personal Innovativeness & 0,869 & 0,878 & 0,926 & 0,959 \\
\hline Satisfaction of Muslim women & 0,880 & 0,898 & 0,943 & 0,985 \\
\hline Loyalty of Muslim women & 0,772 & 0,773 & 0,883 & 0,924 \\
\hline Word of mouth & 0,727 & 0,726 & 0,857 & 0,887 \\
\hline
\end{tabular}

Based on the construct value and reliability test, the outer model has met the criteria. All constructs have met the criteria for the convergent validity test because all AVE and communality values have values above 0.5 . The indicators used also meet the criteria for discriminant validity because the root of AVE is greater than the correlation with other variables. All variables have a composite reliability value above 0.7 , thus proving that the indicator can be used. Inner model testing is done by using the R-square and the path coefficient or t-statistic for each path.

Table 2. R-Square Result.

\begin{tabular}{|l|c|}
\hline \multicolumn{1}{|c|}{ Construct } & R-Square \\
\hline Satisfaction of Muslim women & 0,698 \\
\hline Loyalty of Muslim women & 0,477 \\
\hline Word of mouth & 0,563 \\
\hline
\end{tabular}

Table 3. Path Coefficient Results.

\begin{tabular}{|l|c|c|c|}
\hline & $(\mathbf{O})$ & $(\mathbf{S T D E V})$ & $(\mid \mathbf{O} /$ STERR $\mid)$ \\
\hline Distributive justice -> Satisfaction of Muslim women & 0,479 & 0,075 & $6,394^{*}$ \\
\hline Ease to use -> Satisfaction of Muslim women & 0,111 & 0,064 & $1,726^{*}$ \\
\hline Skill -> Satisfaction of Muslim women & 0,253 & 0,072 & $3,493^{*}$ \\
\hline Interactional justice -> Satisfaction of Muslim women & $-0,072$ & 0,066 & 1,099 \\
\hline Information quality -> Satisfaction of Muslim women & $-0,143$ & 0,105 & 1,218 \\
\hline Load speed -> Satisfaction of Muslim women & 0,087 & 0,053 & 1,621 \\
\hline Innovation-> Satisfaction of Muslim women & $-0,029$ & 0,050 & 0,590 \\
\hline Procedural justice -> Satisfaction of Muslim women & 0,291 & 0,062 & $4,637^{*}$ \\
\hline Satisfaction of Muslim women -> Loyalty & 0,676 & 0,042 & $15,910^{*}$ \\
\hline Satisfaction of Muslim women -> Word of mouth & 0,729 & 0,030 & $24,020^{*}$ \\
\hline Security -> Satisfaction of Muslim women & 0,115 & 0,070 & $1,644^{*}$ \\
\hline Visual appeal -> Satisfaction of Muslim women & $-0,111$ & 0,060 & $1,848^{*}$ \\
\hline
\end{tabular}

* Signifikan (t-hitung $\geq 1,64$ ), $\alpha$ 0,05. 
Table 4. Total Effect.

\begin{tabular}{|c|c|c|c|}
\hline & (O) & (STDEV) & (|O/STERR $\mid)$ \\
\hline Skill -> Satisfaction of Muslim women & 0,292 & 0,087 & $3,342 *$ \\
\hline Personal Innovation -> Satisfaction & 0,016 & 0,064 & 0,255 \\
\hline Distributive justice $->$ Satisfaction & 0,419 & 0,094 & $4,441^{*}$ \\
\hline Distributive justice * Skill -> Satisfaction & $-0,502$ & 0,202 & $2,484 *$ \\
\hline Distributive justice * Pers Innov -> Satisfaction & 0,311 & 0,145 & 2,140 \\
\hline Ease to use $->$ Satisfaction & 0,158 & 0,091 & $1,726^{*}$ \\
\hline Ease to use $*$ Skills $->$ Satisfaction & 0,134 & 0,122 & 1,092 \\
\hline Ease to use * Pers Innov -> Satisfaction & $-0,069$ & 0,092 & 0,757 \\
\hline Interactional justice $->$ Satisfaction & $-0,072$ & 0,076 & 0,962 \\
\hline Interactional justice * Skill -> Satisfaction & 0,111 & 0,116 & 0,959 \\
\hline Interactional justice $*$ Pers Innov $->$ Satisfaction & $-0,112$ & 0,104 & 1,076 \\
\hline Information quality $->$ Satisfaction & $-0,105$ & 0,087 & 1,218 \\
\hline Information quality $*$ Skill $->$ Satisfaction & 0,292 & 0,183 & 1,596 \\
\hline Information quality * Pers Innov -> Satisfaction & 0,129 & 0,162 & 0,801 \\
\hline Load speed -> Satisfaction & 0,137 & 0,059 & $2,300^{*}$ \\
\hline Load speed $*$ Skills $->$ Satisfaction & $-0,017$ & 0,112 & 0,159 \\
\hline Load speed * Pers Innov -> Satisfaction & $-0,186$ & 0,145 & 1,284 \\
\hline Procedural justice $->$ Satisfaction & 0,178 & 0,078 & $2,285^{*}$ \\
\hline Procedural justice $*$ Skill -> Satisfaction & $-0,023$ & 0,152 & 0,152 \\
\hline Procedural justice * Pers Innov $->$ Satisfaction & $-0,143$ & 0,121 & 1,172 \\
\hline Security $->$ Satisfaction & 0,039 & 0,074 & 0,543 \\
\hline Security * Skill -> Satisfaction of Muslim women & 0,040 & 0,108 & 0,374 \\
\hline Security $*$ Pers Innov $->$ Satisfaction & $-0,069$ & 0,112 & 0,613 \\
\hline Visual appeal -> Satisfaction & $-0,059$ & 0,071 & 0,842 \\
\hline Visual appeal * Skill -> Satisfaction & $-0,049$ & 0,117 & 0,417 \\
\hline Visual appeal * Pers Innov -> Satisfaction & 0,052 & 0,087 & 0,600 \\
\hline
\end{tabular}

* Signifikan (t-hitung $\geq 1,64$ ), $\alpha 0,05$.

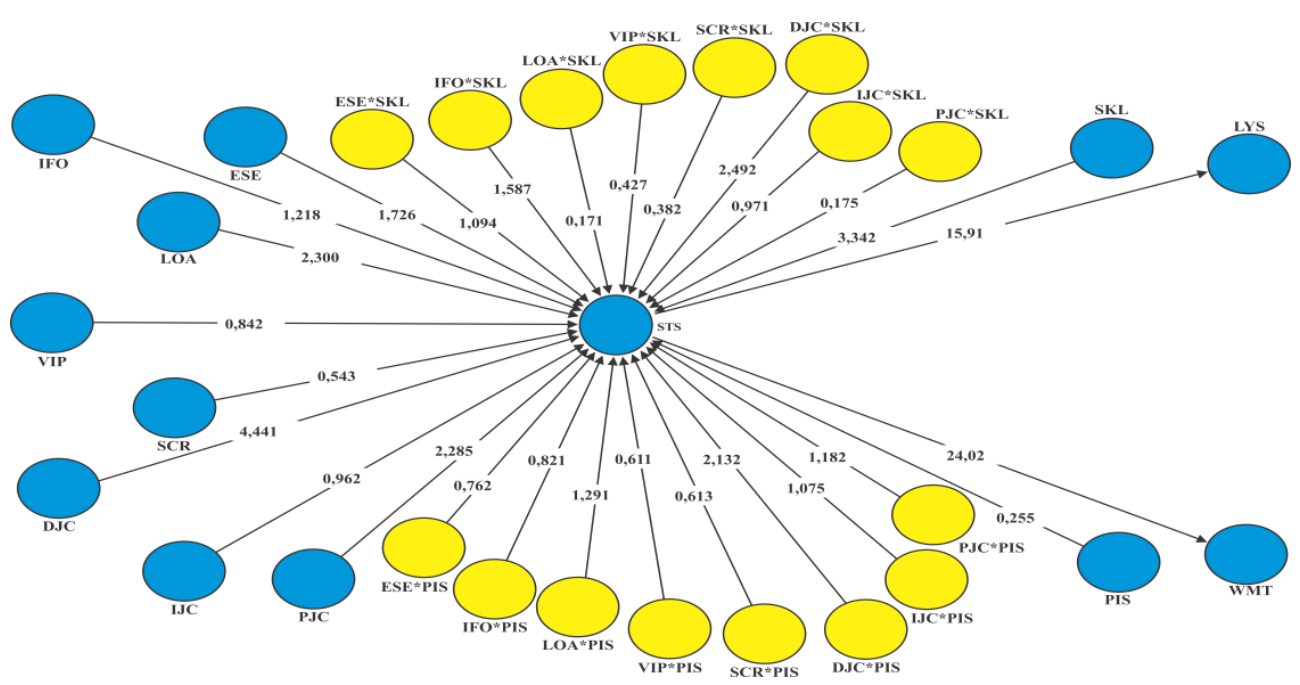

Fig. 1. Output Structural Equation Modeling.

ESE: Ease to Use; IFO: Information Quality; LOA: Load Speed; VIP: Visual Appeal; SCR: Security; DJC: Distributive Justice; IJC: Interactional Justice; PJC: Procedural Justice; STS: Satisfaction of 
Muslim women; PIS: Muslim Women Personal Innovativeness; SKL: Muslim Women Skill; LYS: Loyalty of Muslim Women; WMT: Word of Mouth.

\subsection{Discussion}

\subsubsection{E-service Quality of Mobile Commerce and Satisfaction of Muslim Women}

Ease to use online shopping on mobile commerce has a positive effect on the satisfaction of Muslim women. These findings are in line with the findings of previous researchers $[4,6$, $10,37-39,41-43]$. This is in accordance with the TAM and TRA theory. The higher the ease to use of mobile commerce felt by Muslim women, the higher the satisfaction achieved by customers. This convenience will encourage Muslim women to be satisfied with mobile commerce services. The visual appeal of mobile commerce has a positive effect on Muslim women's satisfaction. The results of this study are in line with the findings of previous research, which states that visual appeal is the strongest dimension in determining user satisfaction $[10,46,53,70]$. Security mobile commerce has a positive effect on the satisfaction of Muslim women. The results of this study follow previous researchers [5, 10, $55-57,71]$ saying that online site security prevents payment errors and plays a vital role in improving e-service quality for online shopping. Distributive justice has a positive effect on Muslim women satisfaction. These findings are in line with research [14, 16-17, 72-73]. Distributive justice is essential for Muslim women because it shows the function of mobile commerce as a store that sells a variety of their needs. Procedural justice has a positive effect on the satisfaction of Muslim women. The results of this study support research [14, 17, 73].

Unlike the dimensions of e-service quality above, information quality does not affect Muslim women's satisfaction. These findings differ from these studies [4, 10]. Muslim women often look for product information purchased from other information sources available on search engines or social media. This is in line with the finding [74] that customer behaviour in online shopping is to first look for as much product information as possible from various sources, including brand image [75-76] and compare product prices on various platforms before shopping online. Load speed does not affect Muslim women's satisfaction in online shopping. Mobile commerce, which Muslim women often use, is an application that is often used in Indonesia. Internet speed is relatively low, so it becomes a problem in online shopping. Therefore, if there are problems related to loading speed, Muslim women usually understand the condition of the internet network in Indonesia and do not think that the mobile commerce application causes the load speed. Thus, the load speed of mobile commerce does not affect the satisfaction of Muslim women when shopping online. Interactional justice does not affect the satisfaction of Muslim women. The results of this study differ from the findings of previous studies [14, 72]. However, the results of this study support the findings [73]. Muslim women are more concerned with results from transactions, not how to interact with mobile commerce. As long as the goods are obtained, Muslim women are satisfied with the mobile commerce service. The majority of customers feel they prefer solving shoppingrelated problems without communicating much with the app.

\subsubsection{E-Service Quality, Satisfaction, Skill dan Innovativeness of Muslim Women}

Muslim women's skill leads to better finding out her right to make online purchases through mobile commerce is not on the dimensions of the other e-service quality. In line with the research [61], expert customers rely more on e-service quality in terms of results or techniques, not on other service quality such as the interaction process with online shopping sites. Personal innovativeness does not moderate the relationship between the dimensions of 
e-service quality and the satisfaction of Muslim women in online shopping [77]. This is because Muslim women are forced to use mobile commerce as an impact and fear of the Covid-19 virus, which creates satisfaction with services. The results of this study support the previous findings [71, 78-79].

\subsubsection{Satisfaction of Muslim Women, Loyalty, and Word of Mouth}

Satisfaction has a positive effect on the loyalty of Muslim women. The results of this study are in line with these studies [10, 54, 87-88, 69, 80, 86]. Muslim women are considering visiting and repurchasing on mobile commerce after feeling satisfaction from their e-service quality. For that, satisfaction can be used as a benchmark for obtaining and retaining Muslim customers. Satisfaction also has a positive effect on word of mouth. The results of this study also support the findings $[1,54,69,71,87,91]$. Customers are willing to convey good things by conducting online customer reviews on the mobile commerce application and even encouraging the propagation through social media.

\section{Conslusion}

Visual appeal, ease to use, security, distributive justice, and procedural justice of mobile commerce affect the satisfaction of Muslim women when online shopping during a pandemic, where the pandemic information quality, load speed, and interactional justice on mobile commerce has a positive influence on the satisfaction of Muslim women doing online shopping. This satisfaction was strengthened by the skill of Muslim women in using mobile commerce. At the same time, Muslim women do not need to have personal innovativeness to gain online shopping satisfaction on mobile commerce. Muslim women who feel satisfied with the service of mobile commerce is doing word of mouth about mobile commerce. The satisfying experience of transacting on mobile commerce encourages the loyalty behaviour of Muslim women to do online shopping during the PSBB three times. This satisfaction also impacts word-of-mouth, which is shown by the online customer review behaviour of Muslim women on the mobile commerce application. This research proves that the justice theory that is respected and upheld in Islam is proven to positively affect Muslim women's satisfaction when online shopping. For this reason, mobile commerce application providers need to reinforce the concept of justice in the marketplace. Future research should examine the existence of the moral economy in online shopping. In addition to testing satisfaction, loyalty, and word of mouth, it is necessary to create a combination model of application service quality, internal user factors, and external user factors such as online customer reviews and lifestyle.

\section{Acknowledgment}

Thank you to State Institute of Islamic Studies (IAIN) Salatiga, especially Faculty of Islamic Economic and Business, which have encouraged the completion of this research and all respondents who helped to collect the data.

\section{References}

1. B. B. Holloway and S. E. Beatty, J. Serv. Res., 6, 1, 92-105 (2003)

2. V. A. Zeithaml, A. Parasuraman, and A. Malhotra, J. Acad. Mark. Sci., 30, 4, (2002)

3. A. Parasuraman, V. A. Zeithaml, and A. Malhotra, J. Serv. Res., 7, 3, 213-233 (2005)

4. M. Fassnacht and I. Koese, J. Serv. Res., 9, 1, 19-37 (2006) 
5. M. Wolfinbarger and M. C. Gilly, J. Retail., 79, 3, 183-198 (2003)

6. Z. Yang and X. Fang, 15, 3, 302-326 (2004)

7 H. H. Bauer, T. Falk, and M. Hammerschmidt, J. Bus. Res., 59, 866-875 (2006)

8. Y. Yi and T. Gong, Psychol. Mark., 25, 7, 587-601 (2008)

9. G. J. Udo, K. K. Bagchi, and P. J. Kirs, Int. J. Inf. Manage., 30, 6, 481-492 (2010).

10. B. Coker, 10, 2, 209-218 (2013)

11. B. Yoo and N. Donthu, Q. J. Electron. Commer, 2, 1, 471-471 (2015)

12. J. D. Wells, J. S. Valacich, and T. J. Hess, MIS Q, 35, 2, 373-396 (2011)

13. E. T. Loiacono, R. T. Watson, and D. L. Goodhue, 11, 3, 51-87 (2007)

14. Y. Fang, C. Chiu, and E. T. G. Wang, Internet Res., 21, 4, 479-503, (2011)

15. A. Giovanis, P. Athanasopoulou, and E. Tsoukatos, J. Serv. Theory Pract., 25, 744-776 (2015)

16. J. G. Blodgett, D. J. Hill, and S. S. Tax, J. Retail., 73, 2, 185-210 (1997)

17. S. S. Tax, S. W. Brown, and M. Chandrashekaran, J. Mark., 62, 2, 60-76 (1998)

18. S. Moorthy, B. T. Ratchford, and D. Talukdar, J. Consum. Res., 23, 4, $263-277$ (1997)

19. J. A and A. Jackson, Advances in Consumer Research (1991)

20. S. Chen, H. Chen, and M. Chen, Ind. Manag. Data Syst., 109, 9, 1248-1263 (2009)

21. F. D. Davis, MIS Q. Manag. Inf. Syst., 13, 3, 319-339 (1989)

22. Y. Lee, K. Kozar, and K. Larsen, Technology, 12 (2003)

23. S. H. Kim, A Study on Adoption Factors of Korean Smartphone Users: A Focus on TAM (Technology Acceptance Model) and UTAUT (Unified Theory of Acceptance and Use of Technology) (2014)

24. A. R. Ashraf, N. (Tek) Thongpapanl, and S. Auh, J. Int. Mark., 22, 3, 68-93, (2014).

25. M. Koufaris, Inf. Syst. Res., 13, 2, 205-223 (2002)

26. F. Driediger and V. Bhatiasevi, J. Retail. Consum. Serv., 48, 224-237 (2019)

27. Renny, S. Guritno, and H. Siringoringo, Procedia - Soc. Behav. Sci., 81, 212-216 (2013)

28. A. R. Ashraf, N. (Tek) Thongpapanl, and S. Spyropoulou, Electron. Commer. Res. Appl., 20, 69-86 (2016)

29. E. W. Morrison and S. L. Robinson, Acad. Manag. Rev., 22, 1, 226-256 (1997)

30. O. Turel, Y. Yuan, and C. Connelly, J. Manag. Inf. Syst., 24, 123-151 (2008)

31. R. C. Huseman, J. D. Hatfield, and E. W. Miles, Acad. Manag. Rev., 12, 2, 222-234, (1987)

32. D. K. Tse and P. C. Wilton, J. Mark. Res., 25, 2, 204-212 (1988)

33. J. A. Colquitt, B. A. Scott, T. A. Judge, and J. C. Shaw, Organ. Behav. Hum. Decis. Process., 100, 1, 110-127 (2006)

34. Y. Cohen-Charash and P. E. Spector, Organ. Behav. Hum. Decis. Process., 86, 2, $278-$ $321(2001)$

35. R. J. Bies and D. L. Shapiro, Soc. Justice Res., 1, 2, 199-218 (1987)

36. E. Lind, Adv. Organ. justice, 56-88, (2001)

37. R. Ramadan and J. Aita, Int. J. Bank Mark., 36, 7, 1213-1234 (2018)

38. M. Amin, S. Rezaei, and M. Abolghasemi, Nankai Bus. Rev. Int., 5, 3, 258-274 (2014)

39. Z. Kalinić, V. Marinković, A. Djordjevic, and F. Liebana-Cabanillas, J. Enterp. Inf. Manag., 33, 1, 71-94 (2020)

40. V. Marinkovic and Z. Kalinic, Online Inf. Rev., 41, 2, 138-154 (2017)

41. P. Raman and K. Aashish, Int. J. Bank Mark., 39, 2, 242-271 (2021)

42. S. Mahapatra, Int. J. Retail Distrib. Manag., 45, 9, 930-949 (2017)

43. S. Choi, Internet Res., 28, 1, 105-122 (2018)

44. C. Shchiglik and S. J. Barnes, J. Comput. Inf. Syst., 44, 3, 17-25 (2004)

45. D. J. Kim, D. L. Ferrin, and H. R. Rao, Decis. Support Syst., 44, 2, 544-564 (2008)

46. D. Cyr and C. Bonanni, Int. J. Electron. Bus., 3, 6, 565 (2005)

47. M. Ramezani Nia and S. Shokouhyar, J. Res. Interact. Mark., 14, 4, 357-389, (2020) 
48. X. Peng, D. Peak, V. Prybutok, and C. Xu, Nankai Bus. Rev. Int., 8, 2, pp. 190-209 (2017) 49. C.-D. Chen, E. C. S. Ku, and C. C. Yeh, Internet Res., 29, 4, 900-920 (2019)

50. Z. Bao and T. Huang, 14, 2, 177-192 (2018)

51. R. Huang and S. Ha, Int. J. Retail Distrib. Manag., 49, 2, 242-262, (2021)

52 E. Ageeva, T. C. Melewar, P. Foroudi, and C. Dennis, Qual. Mark. Res. An Int. J., 22, 5, 687-715 (2019)

53. A. Tarhini, A. A. Alalwan, A. B. Shammout, and A. Al-Badi, Rev. Int. Bus. Strateg., 29, 3, 157-179 (2019)

54. M. Blut, J. Retail., 92, 4, 500-517 (2016)

55. K.-L. Hsiao, K.-Y. Lin, Y.-T. Wang, C.-H. Lee, and Z.-M. Zhang, Electron. Libr., 37, 5, 893-913 (2018)

56. M. A. Hossain, PSU Res. Rev., 3, 3, 179-190 (2019)

57. S. K. Trivedi and M. Yadav, VINE J. Inf. Knowl. Manag. Syst., 48, 3, 427-447 (2018)

58. E. Lee and J. Park, Manag. Serv. Qual. An Int. J., 20, 1, 46-69 (2010)

59. R. T. Grenci and C. A. Watts, Bus. Horiz., 50, 2, 123-132 (2007)

60. Y. Zhang, Y. Fang, K.-K. Wei, E. Ramsey, P. McCole, and H. Chen, Inf. Manag., 48, 6, 192-200 (2011)

61. S. J. Bell, S. Auh, and K. Smalley, J. Acad. Mark. Sci., 33, 2, 169 (2005)

62. M. J. Reinders, R. Frambach, and M. Kleijnen, Eur. J. Mark., 49, 1/2, 190-211 (2015)

63. M. Limayem, M. Khalifa, and A. Frini, Syst. Man Cybern. Part A Syst. Humans, IEEE Trans., 30, 421-432 (2000)

64. R. Ladhari, J. Retail. Consum. Serv., 17, 6, 464-477 (2010)

65. L. Jiang, M. Jun, and Z. Yang, Serv. Bus., 10, 2, 301-317 (2016)

66. E. E. Grandon and J. M. Pearson, Inf. Manag., 42, 1, 197-216 (2004)

67. R. Rauniar, G. Rawski, J. Crumbly, and J. Simms, J. Electron. Commer. Res., 10 (2009)

68. R. Agarwal and J. Prasad, Inf. Syst. Res., 9, 2, 101-2015 (1998)

69. B. Choi and B.-J. Choi, Eur. J. Mark., 48, 1/2, 108-131, (2014)

70. M. Bernardo, F. Marimon, and M. del M. Alonso-Almeida, Inf. Manag., 49, 7, pp. 342347 (2012)

71. K. Chung and J. Shin, Int. J. Bus. Inf., 4, 137-160 (2009)

72. I.-L. Wu, Int. J. Inf. Manage., 33, 1, 166-176 (2013)

73. A. Tolba, I. Seoudi, H. Meshreki, and M. Shimy, Glob. J. Bus. Res., 9, 1-14 (2015)

74. C. Katawetawaraks and C. Wang, Asian J. Bus. Res., 1 (2011)

75. Rosmayani and A. Mardhatillah, J. Islam. Mark., 11, 6, 1419-1441 (2020)

76. A. A. Mohammad Salameh, H. Ahmad, F. Zulhumadi, and F. M. Abubakar, J. Syst. Inf. Technol., 20, 1, 73-102 (2018)

77. D. Shang and W. Wu, Ind. Manag. Data Syst., 117, 1, 213-227 (2017).

78. T. A. Smith, Spanish J. Mark. - ESIC, 24, 2, 155-175 (2020)

79. R. M. Al-dweeri, A. Ruiz Moreno, F. J. L. Montes, Z. M. Obeidat, and K. M. Al-dwairi, Ind. Manag. Data Syst., 119, 4, 902-923 (2019)

80. C.-S. Lu et al., Marit. Bus. Rev., 5, 2, 211-228 (2020)

81. S. Ahmed, M. M. Choudhury, E. Ahmed, U. Y. Chowdhury, and A. Al Asheq, TQM J., 2020)

82. D. Ghorbanzadeh and A. Rahehagh, Rajagiri Manag. J., 15, 1, 16-38 (2021).

83. P. Soni, Am. J. Bus., 36, 1, 20-34 (2021)

84. M. Dayan, I. A. Al Kuwaiti, Z. Husain, P. Y. Ng, and A. Dayan, Int. J. Qual. Reliab. Manag., (2021)

85. J. M. Garcia, O. B. D. L. Freire, E. B. A. Santos, and J. Andrade, Rev. Gestão, 27, no. 3, 211-228 (2020)

86. L. C. Cong, J. Outdoor Recreat. Tour., 33, 100343 (2021) 
87. A. A. Shaikh, H. Karjaluoto, and J. Häkkinen, J. Retail. Consum. Serv., 44, 45-53 (2018)

88. K. L. Khoo, PSU Res. Rev., (2020)

89. N. Meilatinova, Int. J. Inf. Manage., 57, 102300 (2021)

90. A. Özmen and İ. Y. Ögel, Contemporary Issues in Business Economics and Finance, 104, 105-121 (2020)

91. B. Osatuyi, H. Qin, T. Osatuyi, and O. Turel, Comput. Human Behav., 111 (2020) 